\title{
Geology and mineralogy of the Au-As (Ag-Pb-Zn-Cu-Sb) polymetallic deposit of Valiña-Azúmara (Lugo, NW Spain)
}

\author{
Geología y mineralogía del yacimiento polimetálico de Au-As \\ (Ag-Pb-Zn-Cu-Sb) de Valiña-Azúmara (Lugo, NO de España).
}

\author{
I. Martínez-Abad, A. Cepedal, D. Arias, A. Martín-Izard, M. Fuertes-Fuente \\ Departamento de geología de la Universidad de Oviedo. Email: iker@geol.uniovi.es
}

\begin{abstract}
Valiña-Azúmara is a polymetallic Au-As (Ag-Pb-Zn-Cu-Sb) deposit, located in the province of Lugo (NW Spain), that was mined for arsenic at the beginning of the 20th century. The mineralization is hosted in a Variscan thrust fault with a dip direction of $\mathrm{N} 247-261^{\circ} \mathrm{E}$, and N-S and NE-SW Late-Variscan faults. These structures are hosted in black slates, Cambrian in age. To a lesser extent, the mineralization also occurs disseminated within narrow, weakly silicified and sericited selvages. Mineralization is divided into two hypogene stages. The first consists of quartz, calcite, rutile, sericite, arsenopyrite and pyrite. Two types of pyrite (Py-I and Py-II) are defined according to their chemical and textural characteristics. Py-II occurs as overgrowth of previous Py-I crystals. Py-II is As-rich ( $\leq 1.7 \mathrm{wt} . \%$ ) and often contains traces of $\mathrm{Te}, \mathrm{Zn}, \mathrm{Cu}, \mathrm{Bi}, \mathrm{Sb}$ and $\mathrm{Au}$. The mineralized drill core sections show a significant correlation between Au and As. This is due to Au occurring as invisible Au within the Py-II grains, with contents of up to $176 \mathrm{ppm}$. The Au/As ratios of Py-II indicate that Au was deposited as $\mathrm{Au}^{1+}$, as solid solution within the pyrite structure. The second stage of mineralization is enriched in Ag- $\mathrm{Pb}-\mathrm{Zn}-\mathrm{Cu}-\mathrm{Sb}$, replacing the first stage, and consists of quartz, calcite, chlorite, sphalerite, jamesonite, Ag-rich tetrahedrite, freibergite, chalcopyrite, pyrrhotite and galena. Although jamesonite shows traces of $\mathrm{Ag}$, the Cu-Ag sulfosalts are the main carriers of the Ag mineralization in the deposit, with contents that vary from 13.7 to $23.9 \mathrm{wt}$. $\mathrm{of} \mathrm{Ag}$. In the most superficial levels of the area, secondary Fe oxide and hydroxide, scorodite and anglesite developed due to the oxidation of the ore.
\end{abstract}

Keywords: Refractory gold; pyrite; Ag-rich tetrahedrite; freibergite; Vilalba gold district; NW Spain.

\section{RESUMEN}

Valiña-Azúmara es un yacimiento filoniano de Au-As (Ag-Pb-Zn-Cu-Sb) situado en la provincia de Lugo (NO España), que fue explotado por arsénico a principios del siglo XX. La mineralización se encuentra encajada en un cabalgamiento Varisco de dirección de buzamiento N247-261 ${ }^{\circ} \mathrm{E}$ y en fracturas tardivariscas de dirección N-S y NE-SO que cortan a filitas negras de edad Cámbrica. En menor medida la mineralización también se encuentra diseminada en el encajante, en finas salbandas levemente sericitizadas y silicificadas. La mineralización se divide en dos etapas hipogénicas. La primera está constituida por cuarzo, calcita, rutilo, sericita, arsenopirita y pirita. En base a su composición y textura, se diferencian dos tipos de pirita, Py-I y Py II. La Py-II suele encontrarse recrecida sobre la Py I, formando bandas poligonales. Esta pirita está enriquecida en As $(\leq 1,7 \%$ en peso) y contiene trazas de otros metales como $\mathrm{Te}, \mathrm{Zn}, \mathrm{Cu}, \mathrm{Bi}, \mathrm{Sb}$ y Au. Los tramos mineralizados de sondeo del yacimiento

Recibido el 24 de febrero de 2015 / Aceptado el 23 de septiembre de 2015 / Publicado online el 20 de noviembre de 2015

Citation / Cómo citar este artículo: I. Martínez-Abad, et al. (2015). Geology and mineralogy of the Au-As (Ag-Pb-Zn-Cu-Sb) polymetallic deposit of Valiña-Azúmara (Lugo, NW Spain). Estudios Geológicos 71(2): e040. http://dx.doi.org/10.3989/egeol.42059.369.

Copyright: () 2015 CSIC. This is an open-access article distributed under the terms of the Creative Commons Attribution-Non Commercial (by-nc) Spain 3.0 License. 
presentan correlación geoquímica entre los elementos Au y As, debido a que el Au se halla en forma de oro refractario dentro de los cristales de pirita arsenical (Py-II), los cuales Ilegan a presentar concentraciones en Au de hasta 176 ppm. La relación Au/As de la Py-II sugiere que el oro se encuentra en forma de $\mathrm{Au}^{+1}$, en solución sólida dentro de la estructura cristalina del mineral. La segunda etapa de mineralización está enriquecida en $\mathrm{Ag}-\mathrm{Pb}-\mathrm{Zn}-\mathrm{Cu}-\mathrm{Sb}$ y consiste en cuarzo, calcita, clorita, esfalerita, jamesonita, cobres grises (tetraedrita argentífera y freibergita), calcopirita, pirrotina y galena. Esta etapa se encuentra rellenando fracturas y cavidades intersticiales en los minerales de la etapa anterior, reemplazándolos en parte. Los principales minerales portadores de Ag son los cobres grises, con contenidos que varían entre 13,7 y $23,9 \%$ en peso. En la parte más superficial del yacimiento, la alteración supergénica de la mena primaria dio como resultado la formación de óxidos e hidróxidos de hierro, escorodita y anglesita.

Palabras clave: Oro refractario; pirita; tetraedrita argentífera; freibergita; distrito aurífero de Vilalba; NO España.

\section{Introduction}

The polymetallic deposit of Valiña-Azúmara is located in the central sector of the recently discovered Vilalba gold district (Martínez-Abad et al., 2015a), which is situated $25 \mathrm{~km}$ southeast of the city of Vilalba (province of Lugo, NW Spain) (Fig. 1A). In addition to Valiña-Azúmara, the district is composed of the W/Au skarn of Castro de Rei and the $\mathrm{As}-\mathrm{Au}$ (Ag-Pb-Zn-Cu-Sb) polymetallic mineralization of Arcos (Martínez-Abad et al., 2015b). All these deposits are hosted in Cambrian rocks, controlled by Variscan and Late-Variscan structures and spatially related to felsic dikes. Martínez-Abad et al. (2015a) proposed the model of intrusion-related gold systems to explain the mineralization of the Vilalba gold district. In this model, the Castro de Rei skarn and the Valiña-Azúmara mineralization represent a proximal and a distal deposit, respectively, relative to an unexposed post-tectonic calc-alkaline granitoid situated at depth (Fig. 1B).

The mineralization of Valiña-Azúmara was first recognized by Schulz (1835). This author indicated the presence of several old mining works where As-rich pyrite and Sb-bearing galena were extracted. At the beginning of the 20th century a local mining company carried out underground mining works in the area, in the so-called "arsenic mine of Azúmara". According to Amor Meilán (2005), in addition to As, low amounts of $\mathrm{Ag}$ and $\mathrm{Au}$ were recovered in the calcining kiln of the mine. The Valiña-Azúmara mineralization is classified as a vein-type deposit on the metallogenic map of Spain at the scale of 1:1.500.000 (Au; IGME, 1972), whereas on sheet number 8 (Lugo) of the metallogenic map of Spain at the scale of 1:200.000 (IGME, 1975), two mineralizations with unknown morphology are indicated in the area, one of $\mathrm{Au}\left(\mathrm{n}^{\circ} 30\right)$ and the other composed of pyrite,
$\mathrm{Pb}$ and $\mathrm{Ag}\left(\mathrm{n}^{\circ} 29\right)$. Later, González Lodeiro et al. (1982) made a first description of the ore present in the arsenic mine of Azúmara, identifying löllingite, jamesonite, galena, tetrahedrite and pyrite. In 1998, the Outokumptu mining company started to operate in the area, executing a number of exploration works, including several drill holes. In addition, this company carried out multi-element analysis ( $\mathrm{Au}, \mathrm{As}, \mathrm{Ag}$, $\mathrm{Pb}, \mathrm{Zn}, \mathrm{Cu}, \mathrm{Sb}, \mathrm{Bi}, \mathrm{Mo}, \mathrm{Te}$, and $\mathrm{Tl}$ ) of the mineralized sections of the drill cores.

This paper describes the mineral paragenesis and the structural controls of the Valiña-Azúmara deposit. Moreover, it provides a detailed petrographical, mineralogical, compositional and textural description of the metallic minerals present in the deposit. The electron microprobe analyzer (EMPA) and the scanning electron microscope (SEM) were employed for the compositional and textural description of the mineral phases, allowing us to recognize that $\mathrm{Au}$ mineralization occurs as refractory $\mathrm{Au}$ in As-rich pyrite and $\mathrm{Cu}$ and $\mathrm{Pb}$ sulfosalts bear the silver mineralization in the deposit. Finally, the multi-element analysis carried out in the mineralized sections of the drill cores permit us to geochemically characterize the mineralization of Valiña-Azúmara as well as define correlations between the analyzed elements.

\section{Geological setting}

The Valiña-Azúmara deposit is located in the Mondoñedo Nappe Domain of the West AsturianLeonese Zone (WALZ), within the Iberian Massif (Fig. 1A). In this Domain, the sedimentary rocks consist of a thick preorogenic sequence mainly composed of Cambrian and Ordovician rocks and, to a lesser extent, Silurian rocks (Martínez Catalán, 1985; Pérez-Estaún et al., 1990). 


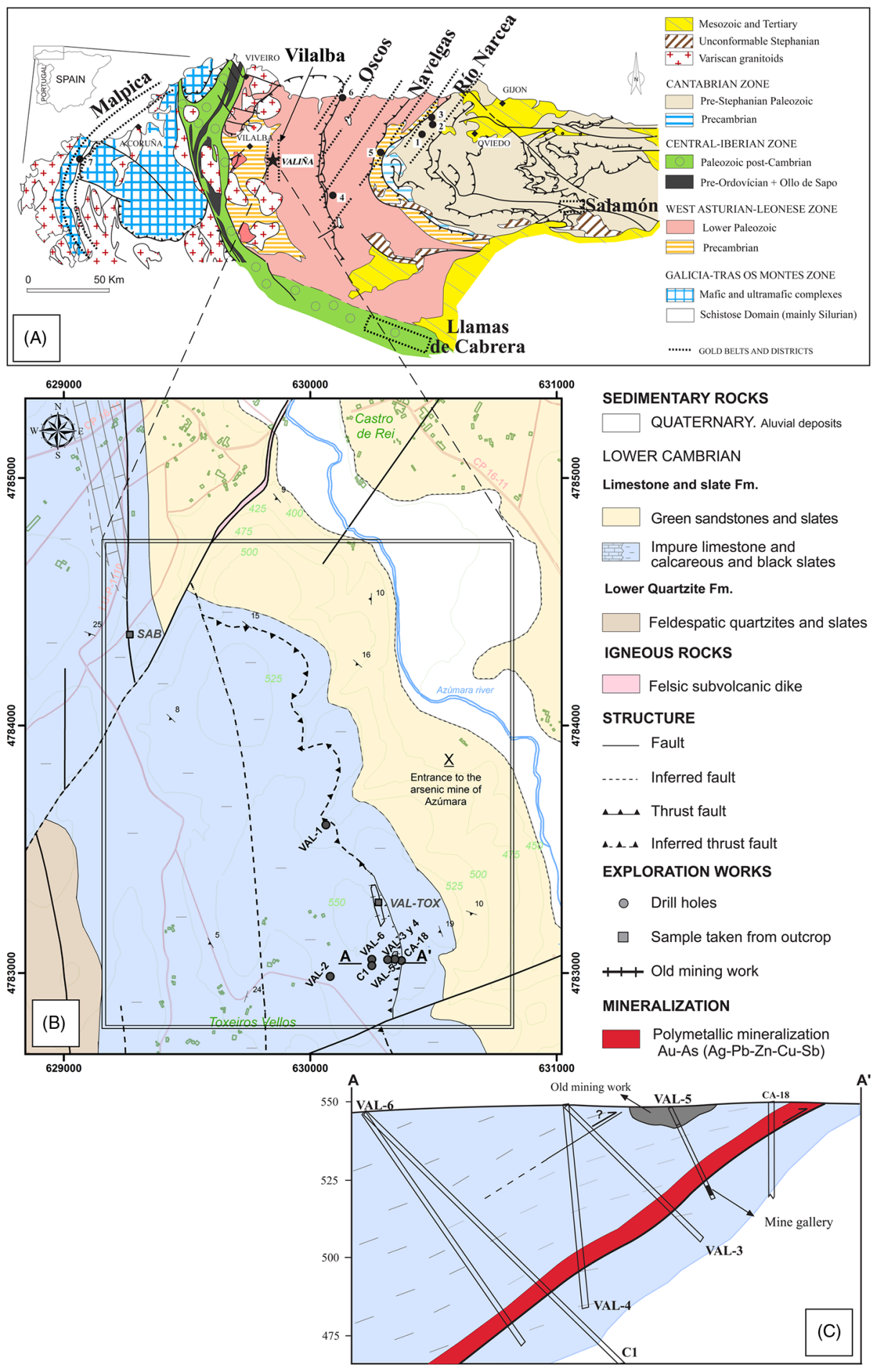

Fig. 1.-A. Regional geology map of the NW of the Iberian Massif showing the gold belts defined by Spiering et al. (2000) (Río Narcea, Navelgas, Oscos and Malpica) and the gold districts of Salamón (Crespo et al., 2000), Llamas de Cabrera (Gómez-Fernández et al., 2012) and Vilalba (Martínez-Abad et al., 2015a). The location of the Valiña-Azúmara deposit and the most important gold deposits are also included: (1) El Valle-Boinás, (2) Carlés, (3) Ortosa, (4) Ibias, (5) Linares, (6) Salave and (7) Corcoesto. B. Geological map of the Valiña-Azúmara area. The location of the cross section A-A' and the samples taken from outcrops (VAL-TOX and SAB) are also included. C. A-A' cross section of the Valiña-Azúmara area. 
The Mondoñedo Nappe Domain was affected by three coaxial deformation phases related to an E-W shortening (Bastida et al., 1986; Martínez Catalán, 1985; Martínez Catalán et al., 1990). The first $\left(\mathrm{D}_{1}\right)$ produced large recumbent and overturned folds, and a generalized slaty cleavage $\left(\mathrm{S}_{1}\right)$. The second $\left(\mathrm{D}_{2}\right)$ was responsible for thrust-type structures and associated shear zones. The third $\left(\mathrm{D}_{3}\right)$ gave rise to large open folds, approximately homoaxial with the $\mathrm{D}_{1}$ folds, intense fracturing and shear zones and local crenulation cleavage $\left(\mathrm{S}_{3}\right)$. Regional metamorphism increases towards the west from greenschist to amphibolite facies. Later, during the Late-Variscan NE-SW, NW-SE, E-W and $\mathrm{N}-\mathrm{S}$ trending fault systems dissected the NW of the Iberian Peninsula (Capote, 1983).

Variscan granitic intrusions are abundant in the western part of the Mondoñedo Nappe Domain (Fig. 1A). They are grouped in a N-S trending thermal metamorphic belt called the Lugo Dome. Based on their composition and their relation with the Variscan stages of deformation, the Variscan granitic intrusions are divided into three main groups: syntectonic calc-alkaline granites, aluminous leucogranites and post-tectonic calc-alkaline granites (Capdevila, 1969, Bellido Mulas et al., 1987, Corretgé et al., 1990). The Valiña-Azúmara deposit is located in the eastern zone of the Lugo Dome, where post-tectonic calcalkaline granites like that of Lugo and Castroverde (287 Ma; Cocherie, 1978) dominate.

\section{Sampling and analytical methods}

The samples were taken from outcrops and drill cores in ore-bearing zones and barren zones at the Valiña-Azúmara area. They were studied by transmitted and reflected light microscopy, SEM (MEB JEOL-6610LV) and EPMA (Cameca SX100) at the University of Oviedo. In the electron microprobe analyses, the standard deviation of results is less than $0.1 \%$. The composition of the metallic minerals was determined at $20 \mathrm{kV}$ accelerating potential, $20 \mathrm{nA}$ beam current and an acquisition time of between 10 and $20 \mathrm{~s}$ for X-ray peak and background. Natural and synthetic certified standards were used to calibrate the quantitative analyses. Moreover, more than 170 selected analyses were performed on potential Au-bearing pyrite and arsenopyrite with the following lower limits of detection: $140 \mathrm{ppm} \mathrm{Au}, 100 \mathrm{ppm}$
Te, 80 ppm Zn, 460 ppm Bi, 150 ppm Co, 60 ppm $\mathrm{Cu}, 80 \mathrm{ppm} \mathrm{Sb}, 100 \mathrm{ppm} \mathrm{Ag}$ and 80 ppm Ni (95\% confidence), using the Cameca SX100 with the following operating conditions: $20 \mathrm{kV}$ accelerating potential, $200 \mathrm{nA}$ beam current, and acquisition times of 60 ( $\mathrm{Co}$ and $\mathrm{Zn}$ ), 120 (Sb, Te, Ni, Ag, Cu and Bi), $180(\mathrm{Se})$ or $240(\mathrm{Au}) \mathrm{s}$ for X-ray peak and background.

The multi-element analyses provided by the mining company were carried out on $1 \mathrm{~m}$ in thick mineralized sections of the drill cores CA-18, CA-1, VAL-1 y VAL-2 (Fig. 1B and 1C). The analyses were carried out in the OMAC laboratory (Galway, Ireland). The analyzed trace elements were $\mathrm{Au}, \mathrm{As}$, $\mathrm{Ag}, \mathrm{Pb}, \mathrm{Zn}, \mathrm{Cu}, \mathrm{Sb}, \mathrm{Bi}, \mathrm{Mo}, \mathrm{Te}$, and Tl. Samples were digested in aqua regia and then analyzed by inductively coupled plasma optical emission spectrometry (ICP-OES).

\section{Local Geology}

The sedimentary rocks in the area of ValiñaAzúmara belong to the Lower Quartzite Fm. and the Limestone and Slate Fm. (Lower Cambrian, Walter, 1966). These rocks were affected by the Variscan regional metamorphism in the grade of the biotite. The Quartzite Fm. consists of quartzite, sandstone and slate. The Limestone and Slate Fm. can be divided into two members (Fig. 1B). The lower one hosts the whole of the mineralization in Valiña-Azúmara. It consists of black slates, $150 \mathrm{~m}$ in thickness. Under the microscope, they have a lepidoblastic texture and consist of quartz, biotite and minor organic matter and calcite. The upper member is formed by green sandstone and slate. Alluvial quaternary rocks fill the alluvial plain of the Azúmara river.

The Valiña-Azúmara deposit is hosted in the inverted limb of the recumbent and overturned syncline of Real developed during the first Variscan phase $\left(D_{1}\right)$. The associated cleavage $\left(S_{1}\right)$ has a dip direction of $\mathrm{N} 222-250^{\circ} \mathrm{E}$ and dips between $5^{\circ}$ and $25^{\circ}$. During the second phase, a thrust-fault with a dip direction of $\mathrm{N} 247-261^{\circ} \mathrm{E}$ and a dip of $35^{\circ}$ affected the inverted limb of the syncline (Fig. 1B and 1C). This structure cut the black slates of the Limestone and Slate Fm. Later, all these structures were crosscut by N-S, E-W and NE-SW trending Late-Variscan faults. The N-S trending faults have a dip direction of $\mathrm{N} 266-285^{\circ} \mathrm{E}$ and dip between $70^{\circ}$ and $90^{\circ}$. 
The south sector of the study area is affected by a $\mathrm{E}-\mathrm{W}$ fault with a dip direction of $\mathrm{N} 172^{\circ} \mathrm{E}$ and a dip of $70^{\circ}$. The NE-SW faults occur in the north section of the study area. They show a dip direction of $\mathrm{N} 300-309^{\circ} \mathrm{E}$ and dip between $55^{\circ}$ and $68^{\circ}$. One of these faults hosts a subvolcanic felsic dike, which was already identified by González Lodeiro et al. (1979). The dike is of up to $5 \mathrm{~m}$ in thickness and extends almost $1 \mathrm{~km}$ to the northeast, crossing the village of Castro de Rei. Geochemically, this subvolcanic rock is high- $\mathrm{K}$, calc-alkaline and peraluminous, classified as rhyolite (Martínez-Abad et al., 2015a). It consists of quartz, plagioclase, K-feldspar and biotite with amphibole, monazite, allanite, apatite and zircon as accessory minerals. According to these authors, it represents the evolved facies of an unexposed post-tectonic calc-alkaline granite located at depth in the Castro de Rei surroundings (Fig. 1B).

\section{Mineralization}

The mineralization in Valiña-Azúmara is structurally controlled. It is mainly associated with the thrust fault $\left(\mathrm{D}_{2}\right)$. In this structure, the ore occurs cementing the fault breccias and, to a lesser extent, disseminated in weakly silicified and sericitized metasedimentary host rocks (fault breccias and narrow selvages around the structure) (Fig. 2). Based on the old mining works and the drill holes carried out in the area by the mining company, it is estimated that the mineralized structure is at least $720 \mathrm{~m}$ long, reaches $75 \mathrm{~m}$ in depth and up to $5 \mathrm{~m}$ in thickness (Fig. 1C). To a lesser extent, the mineralization in the area is also found filling hydrothermal veins of up to $5 \mathrm{~cm}$ in thickness that seal fractures of the N-S and NE-SW Late-Variscan faults. On some occasions, these veins spread laterally a few centimeters (up to $4 \mathrm{~cm}$ ) along $S_{1}$ cleavage planes. In addition to filling the veins, the ore also occurs disseminated in fault breccias and narrow selvages of up to $4 \mathrm{~cm}$ in thickness that are weakly hydrothermally altered (silicified and sericitized) (Fig. 2B, 2C and 2D).

The mineralization developed in two hypogene stages. The first is characterized by a Au-As metal association whereas the second shows a Ag-Pb-Zn-Cu-Sb metal association. Eventually, widespread weathering affected the superficial levels of the area. A supergenic stage consisting of secondary minerals was formed during the weathering and oxidation of the ore. Figure 3 shows the paragenetic sequence of the Valiña-Azúmara deposit.

\section{Lithogeochemistry}

The multi-element analyses show that the mineralized sections of drill core contain variable amounts of $\mathrm{Au}, \mathrm{As}, \mathrm{Ag}, \mathrm{Pb}, \mathrm{Zn}, \mathrm{Cu}$ and $\mathrm{Sb}$ (Table 1). These samples have contents in Au of up to $2.06 \mathrm{ppm}$, in As up to $12.7 \%$; in $\mathrm{Ag}$ up to $487 \mathrm{ppm}$; in $\mathrm{Pb}$ up to $4.4 \%$; in $\mathrm{Cu}$ up to $600 \mathrm{ppm}$; in $\mathrm{Zn}$ up to $1.5 \%$ and in Sb up to 3600 ppm (Table 1). In all the analyzed samples, the content of $\mathrm{Mo}, \mathrm{Bi}, \mathrm{Te}$ and $\mathrm{Tl}$ was below the minimum limit of detection.

Geochemically, $\mathrm{Au}$ shows a low but significant correlation with As $\left(R^{2}=0.66\right.$; Fig. $\left.4 \mathrm{~A}\right)$. One analysis was omitted in the estimation of the correlation coefficient between both elements due to its strong dispersion compared to the rest of the analyses. Au shows no correlation with the rest of analyzed elements. With regard to the Ag, it shows a strong correlation with $\mathrm{Cu}\left(\mathrm{R}^{2}=0.9\right)$ (Fig. 4B). Similar to $\mathrm{Au}$, Ag shows no significant correlation with the rest of analyzed elements.

\section{First stage of mineralization (Au-As)}

This stage of mineralization consists of arsenopyrite and minor pyrite. The ore occurs filling fractures and cementing fault breccias as well as disseminated in the hydrothermally altered metasedimentary host rocks (Fig. 2). Sealing veins and fault breccias, arsenopyrite and pyrite occur together with quartz and minor calcite. In the hydrothermally altered zones, sulfides occur isolated or forming aggregates of a few crystals appearing along $S_{1}$ cleavage planes (Fig. 5A). These aggregates often occur as pseudomorphic replacements of the previous grains of biotite, evidencing sulfidation processes. Thus, the biotite is altered to muscovite together with rutile and fine-grained pyrite and arsenopyrite (Fig. 5B).

Arsenopyrite is the main ore mineral of this stage of mineralization. It occurs disseminated in the hydrothermally altered metasedimentary host-rocks as isolated grains or forming aggregates of a few grains together with the pyrite. In the altered zones, 

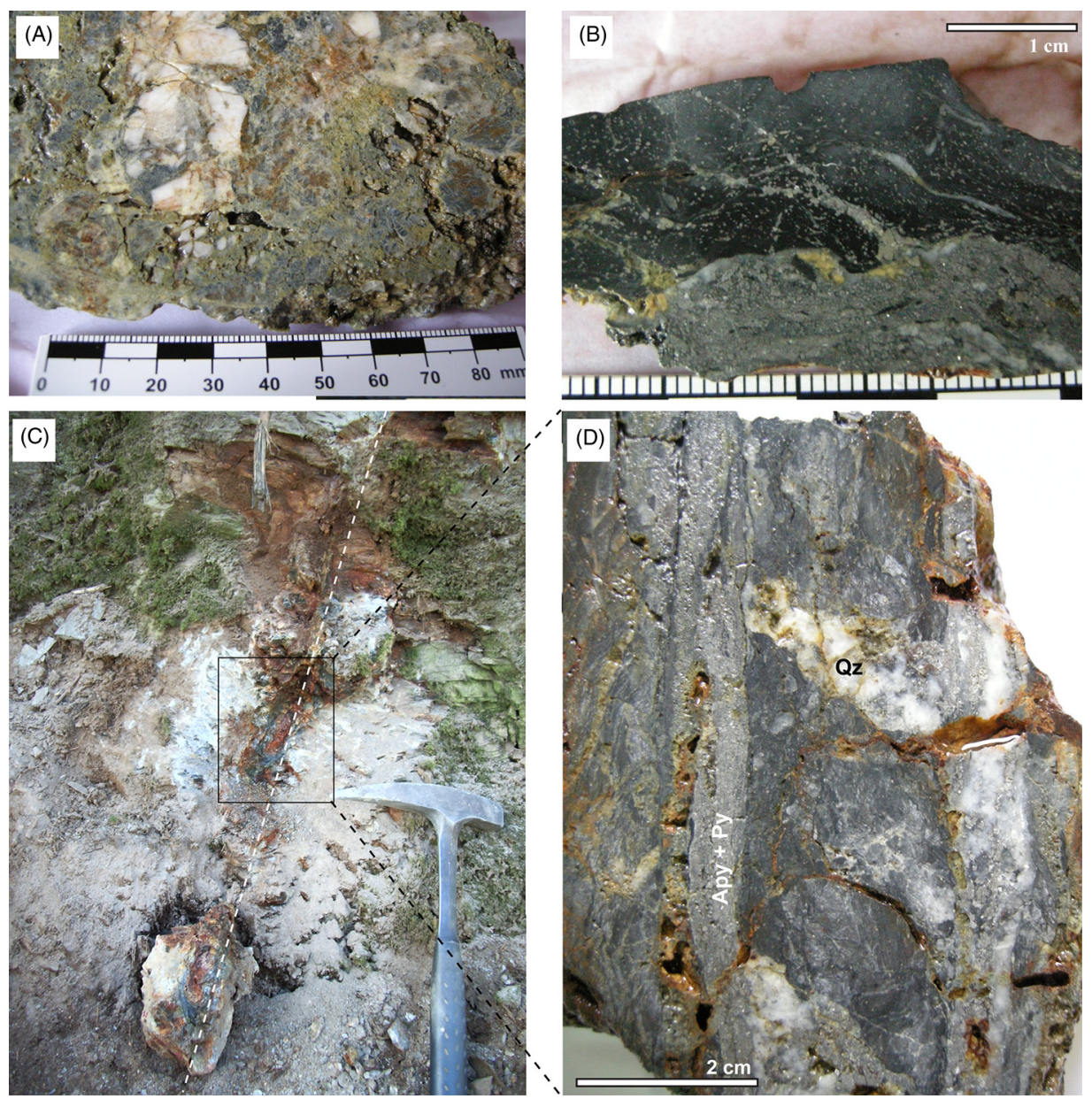

Fig. 2.-A. Fault breccia sample taken from an old mining work in the Valiña-Azúmara area (VAL-TOX in the map of Fig. 1B). Weathering affected the sample, producing the supergene alteration of the primary ore. The main secondary minerals recognized are iron oxides and hydroxides (reddish crust) and scorodite (pale green crust). B. Sample of veins composed mainly of arsenopyrite, quartz and minor pyrite hosted in weakly silicified and sericitized black slates. The ore mineralization is also disseminated in the host rock along $\mathrm{S}_{1}$ cleavage planes. C. Subvertical Late Variscan fault sealed by hydrothermal veins located in the north sector of Valiña-Azúmara ("SAB" in the map of Fig. 1B). D. Sample taken from the N-S Late-Variscan fault of photo "C". The ore mineralization occurs filling the $\mathrm{N}-\mathrm{S}$ fractures as well as disseminated in the adjacent hydrothermally altered black slate. In the sample, tension gashes mainly filled by quartz are also observed.

the arsenopyrite is subhedral to anhedral in shape, with diameter that commonly varies between 5 and $100 \mu \mathrm{m}$ (Fig. 5B), and rarely reach $500 \mu \mathrm{m}$. When arsenopyrite occurs as a filling phase in veins and fault breccias, it forms subhedral crystals, up to $1 \mathrm{~mm}$ in diameter, that are isolated or in aggregates of several grains intergrown with the pyrite and the gangue minerals. The EMPAs performed on the arsenopyrite indicate that the As content of this mineral varies from 43.45 to 46.9 wt.\% (30.8 to 34.1 at.\%). The arsenopyrite crystals commonly display an oscillatory zoning in As, showing an As-poor core with respect to the rims. Moreover, arsenopyrite often shows impurities of $\mathrm{Sb}$ (of up to $0.17 \mathrm{wt} . \%$ ) and $\mathrm{Cu}(\leq 195 \mathrm{ppm}$ ), and on some occasions of $\mathrm{Ni}(\leq 116 \mathrm{ppm})$ (Table 2$)$. It should be noted that in the 49 EMPAs performed on this mineral, the Au concentration was always below the minimum limit of detection.

Pyrite is less abundant and commonly of smaller size than arsenopyrite. According to its textural characteristics under optical microscopy and BSE images, in addition to its chemical composition (Table 3), pyrite has been divided into two types: Py-I and Py-II. 


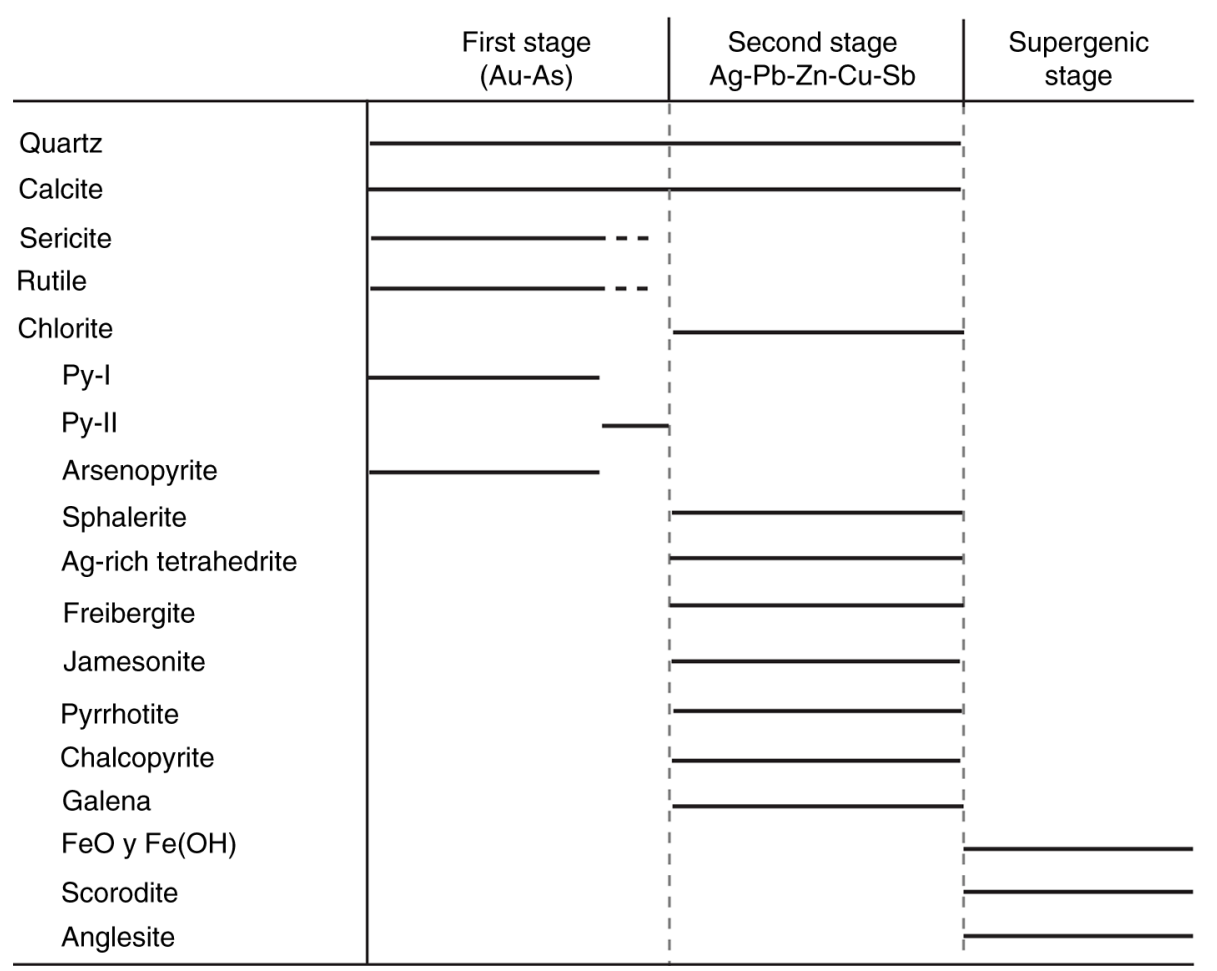

Fig. 3.-Paragenetic sequence of the Valiña-Azúmara deposit.

Py-I occurs intergrown with quartz and calcite grains filling veins and fault breccias as well as disseminated in the hydrothermally altered metasedimentary host rocks. It forms subhedral to anhedral grains of porous appearance and of up to $500 \mu \mathrm{m}$ in diameter (Fig. 5C and 5D). Py-I is normally intergrown with the arsenopyrite, evidencing its coeval precipitation (Fig. 5B). Py-I commonly forms a core overgrown and partially corroded by the other type of pyrite that will be described later. Chemically, the

Table 1.- Median and maximum concentration of $\mathrm{Au}$, $\mathrm{As}, \mathrm{Ag}, \mathrm{Sb}, \mathrm{Cu}, \mathrm{Pb}$ and $\mathrm{Zn}$ obtained in the multi-element analyses ( 31 in total) carried out on mineralized sections of drill cores in Valiña-Azúmara. Detection limits (in ppm): 0.00005 (Au); 50 (As); 2 (Ag); 20 (Sb); 1 (Cu); 15 (Pb); 1 (Zn)

\begin{tabular}{lrr}
\hline (ppm) & Max. & Median \\
\hline $\mathrm{Au}$ & 2.06 & 0.09 \\
$\mathrm{As}$ & 127238 & 4624 \\
$\mathrm{Ag}$ & 487 & 11 \\
$\mathrm{Sb}$ & 3600 & 300 \\
$\mathrm{Cu}$ & 600 & 51 \\
$\mathrm{~Pb}$ & 44741 & 298 \\
$\mathrm{Zn}$ & 15200 & 288 \\
\hline
\end{tabular}

EMPAs carried out on Py-I indicate that it is poor in As ( $<0.2$ wt.\%), and often contains impurities of $\mathrm{Cu}$ $(\leq 117 \mathrm{ppm})$ and, on some occasions, of $\mathrm{Te}(\leq 598$ ppm) and $\mathrm{Zn}(\leq 412 \mathrm{ppm})$ (Table 3$)$.

Py-II forms polygonal bands enriched in As, overgrowing and partially corroding the previous Py-I (Fig. 5C and 5D). On some occasions, both pyrites occur separated by a narrow band of gangue minerals. Py-II was formed after both arsenopyrite and Py-I precipitation, representing the last ore mineral of the first stage of mineralization. Chemically, Py-II is characterized by an enrichment in As from 0.8 to 1.7 wt.\% (Table 3). Apart from As, impurities of other trace elements are commonly present, with $\mathrm{Zn}$ reaching $271 \mathrm{ppm}$, $\mathrm{Cu}$ reaching $124 \mathrm{ppm}$ and $\mathrm{Sb}$ reaching $265 \mathrm{ppm}$. In addition, Py II can occasionally contain trace amounts of $\mathrm{Bi}(\leq 0.19$ wt. $\%), \mathrm{Ni}$ $(\leq 100 \mathrm{ppm})$ and $\mathrm{Te}(\leq 200 \mathrm{ppm})$. Moreover, in this pyrite traces of $\mathrm{Au}$, with concentrations of up to 176 ppm, have also been detected (Table 3, Fig. 5). This fact would explain the correlation between $\mathrm{Au}$ and As obtained in the multi-element analyses carried out on the mineralized sections of drill cores (Fig. 4A). 
(A)

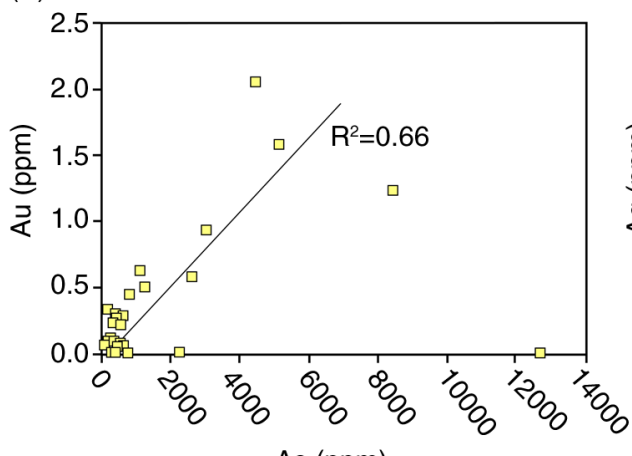

(B)

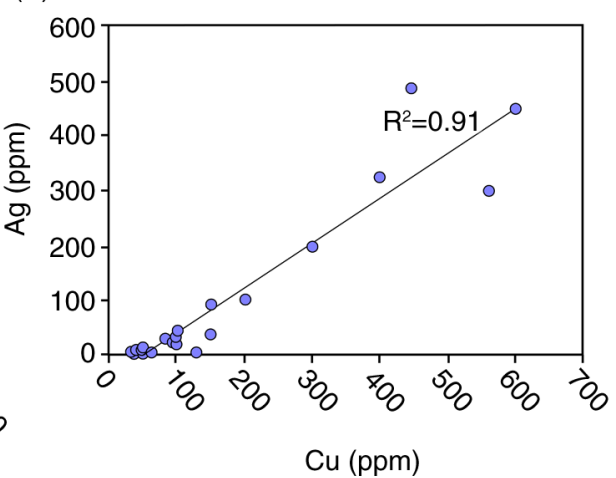

Fig. 4.-Au-As (A) and Ag-Cu (B) plots of the mineralized sections of drill cores from Valiña-Azúmara.
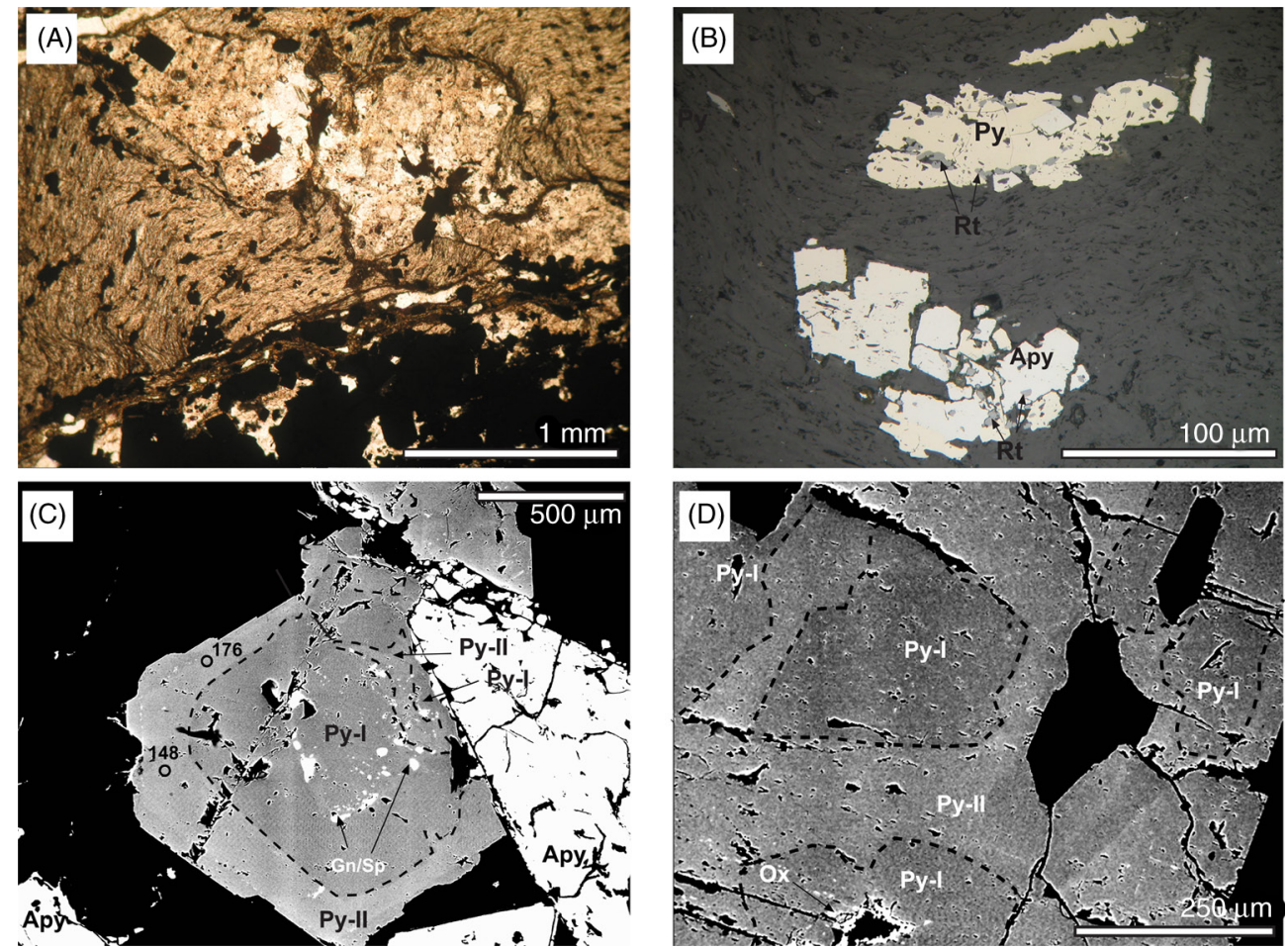

Fig. 5.-A. Photomicrograph under plane polarized light (PPL) of the metallic minerals of the first stage of mineralization. They are hosted in a vein together with quartz and disseminated in the weakly sericitized slaty host rock along $\mathrm{S}_{1}$ cleavages planes. B. Photomicrograph, under reflected light (RL), of arsenopyrite (Apy) and pyrite (Py) of the first stage of mineralization. These minerals are associated with rutile (Rt) crystals. C. BSE image of a zoned pyrite constituted by a core of porous As-poor pyrite (Py-I) overgrown and partially replaced by As-rich pyrite (Py-II). The grain contains small inclusions of sphalerite (Sp) and galena (Gn). The position of EMPAs and gold concentration (ppm) is indicated. D. BSE image of an aggregate of several zoned pyrite grains constituted by As-poor cores of Py-I overgrown by As-rich Py-II.

\section{Refractory Au in pyrite}

In accordance with the EMPAs previously shown, $\mathrm{Au}$ in Valiña-Azúmara occurs as refractory or invisible Au within As-rich pyrite grains (Py-II). According to Deditious et al. (2014), the presence of refractory
$\mathrm{Au}$ in pyrite has been observed in numerous types of $\mathrm{Au}$ deposit including Carlin type, porphyry $\mathrm{Cu}$, epithermal $\mathrm{Au}$, orogenic $\mathrm{Au}$, volcanogenic massive sulfide, iron oxide $\mathrm{Cu}-\mathrm{Au}$ and paleoplacer $\mathrm{Au}$ deposits. Within NW Spain, in addition to the Vilalba gold district, refractory $\mathrm{Au}$ has been identified in the deposits 
Table 2.-Representative composition of the arsenopyrite of Valiña-Azúmara measured by electron microprobe analyses

\begin{tabular}{|c|c|c|c|c|c|c|c|c|c|c|c|c|}
\hline Sample & SAB1 & SAB1 & SAB1 & SAB1 & SAB1 & SAB1 & SAB1 & SAB1 & SAB1 & SAB1 & SAB1 & SAB1 \\
\hline Analysis & 140 & 139 & 141 & 142 & 143 & 144 & 145 & 146 & 147 & 148 & 149 & 150 \\
\hline \multicolumn{13}{|l|}{$w t . \%$} \\
\hline$S$ & 21.28 & 20.14 & 19.60 & 19.53 & 19.88 & 18.84 & 19.27 & 18.92 & 19.17 & 18.96 & 19.76 & 19.35 \\
\hline $\mathrm{Fe}$ & 35.47 & 35.07 & 34.99 & 35.01 & 35.22 & 34.76 & 34.89 & 34.70 & 34.70 & 34.83 & 35.14 & 35.07 \\
\hline As & 43.45 & 45.46 & 45.78 & 45.82 & 45.72 & 46.93 & 45.99 & 46.66 & 46.46 & 46.84 & 45.52 & 46.04 \\
\hline Co & - & - & - & - & - & - & - & - & - & - & - & - \\
\hline $\mathrm{Zn}$ & - & - & - & - & - & - & - & - & - & - & - & - \\
\hline $\mathrm{Bi}$ & - & - & - & - & - & - & - & - & - & - & - & - \\
\hline $\mathrm{Cu}$ & 0.01 & 0.02 & 0.01 & - & 0.01 & - & 0.01 & - & 0.01 & 0.02 & 0.01 & 0.01 \\
\hline $\mathrm{Sb}$ & - & - & 0.10 & 0.13 & 0.10 & 0.17 & 0.04 & 0.06 & 0.04 & 0.08 & 0.05 & 0.17 \\
\hline $\mathrm{Au}$ & - & - & - & - & - & - & - & - & - & - & - & - \\
\hline $\mathrm{Ni}$ & 0.01 & 0.01 & - & - & - & - & - & - & 0.01 & - & - & - \\
\hline $\mathrm{Te}$ & - & - & - & - & - & - & - & - & - & - & - & - \\
\hline $\begin{array}{l}\text { Total } \\
\text { atomic \% }\end{array}$ & 100.22 & 100.69 & 100.47 & 100.48 & 100.94 & 100.69 & 100.20 & 100.33 & 100.39 & 100.71 & 100.48 & 100.64 \\
\hline$S$ & 35.34 & 33.74 & 33.07 & 32.97 & 33.33 & 31.99 & 32.69 & 32.18 & 32.54 & 32.14 & 33.28 & 32.69 \\
\hline $\mathrm{Fe}$ & 33.78 & 33.68 & 33.86 & 33.89 & 33.85 & 33.85 & 33.93 & 33.85 & 33.82 & 33.86 & 33.93 & 33.97 \\
\hline As & 30.84 & 32.54 & 33.01 & 33.06 & 32.76 & 34.07 & 33.34 & 33.92 & 33.75 & 33.94 & 32.76 & 33.24 \\
\hline $\mathrm{Cu}$ & 0.01 & 0.02 & 0.01 & & 0.01 & & 0.01 & & 0.01 & 0.02 & 0.01 & 0.01 \\
\hline $\mathrm{Sb}$ & & & 0.04 & 0.06 & 0.04 & 0.08 & 0.02 & 0.03 & 0.02 & 0.03 & 0.02 & 0.08 \\
\hline $\mathrm{Ni}$ & 0.01 & 0.01 & & & & & & & 0.01 & & & \\
\hline
\end{tabular}

-: below the minimum limit of detection.

of Salave (Martín-Izard \& Rodríguez-Terente, 2009), Salamón (Paniagua et al., 1996; Crespo et al., 2000; Fadón Loro, 2007), El Valle-Boinás (Cepedal et al., 2008) and Ibias (Villa et al., 1993) (Fig. 1A). Similar to Valiña-Azúmara, in all these deposits Au appears within As-rich pyrites that often contain traces of other elements. Furthermore, in all these deposits the presence of refractory $\mathrm{Au}$ within arsenopyrite grains is also common. However, as previously mentioned, $\mathrm{Au}$ was not detected in the arsenopyrite of Valiña-Azúmara.

In agreement with Bakken et al. (1989), Friedl et al. (1995), Simon et al. (1999a,b), Cabri et al. (2000), Palenik et al. (2004) and Reich et al. (2005), Au in As-rich pyrite and arsenopyrite occurs as solid solution $\left(\mathrm{Au}^{+1}\right)$ and as nanoparticles of native $\mathrm{Au}\left(\mathrm{Au}^{0}\right)$. Reich et al. (2005) defined the empirical solid solubility of $\mathrm{Au}$ in As-pyrite as $\mathrm{C}_{\mathrm{Au}}=0.02 \times \mathrm{C}_{\mathrm{As}}+4 \times 10^{-5}$ for a range of temperatures between $150-250{ }^{\circ} \mathrm{C}$, in which $\mathrm{C}_{\mathrm{Au}}$ and $\mathrm{C}_{\mathrm{As}}$ represent the concentration of $\mathrm{Au}$ and As expressed as an atomic percentage (at.\%) (Fig. 6). The line established by this equation describes the solubility limit of $\mathrm{Au}$ in pyrite. The points falling below this line contain $\mathrm{Au}^{+1}$ while the points falling above it contain $\mathrm{Au}^{0}$. The Au-As stage of mineralization in Valina-Azúmara took place at temperatures over $355^{\circ} \mathrm{C}$ (Martínez-Abad et al., 2015a). However, Deditious et al. (2014) recently studied Au-bearing As-rich pyrites from different hydrothermal deposit styles (porphyry $\mathrm{Cu}$, orogenic gold, metamorphic VMS and IOCG) that formed at higher temperatures than $250{ }^{\circ} \mathrm{C}$ (up to $400{ }^{\circ} \mathrm{C}$ ). These authors concluded that the line of solubility of Au proposed by Reich et al. (2005) barely changes except in the case of metamorphic VMS and orogenic gold deposits, where the solubility limit can be altered as a result of complex recrystallization histories, high temperature alteration or cooling, leading to $\mathrm{Au}$ remobilization and growth of post-depositional $\mathrm{Au}$, not observed in Valiña-Azúmara. In addition, these authors observed that the As-rich pyrites from high temperature deposits are generally plotted under the line of solubility of $\mathrm{Au}$, indicating they were formed from solutions that were not saturated in Au.

As mentioned previously, Au in Valiña-Azúmara occurs within the As-rich pyrite grains (Py-II). In the 
Table 3.-Representative composition of the pyrite of Valiña-Azúmara measured by electron microprobe analyses

\begin{tabular}{|c|c|c|c|c|c|c|c|c|c|c|c|c|}
\hline Sample & Py-I & Py-I & Py-I & Py-I & Py-I & Py-II & Py-II & Py-II & Py-II & Py-II & Py-II & Py-II \\
\hline Analysis & S_129 & S_151 & S_18/1 & S_154 & S_161 & S_7/1 & S_26/1 & S_156 & S_157 & S_158 & S2_46/1 & S_160 \\
\hline \multicolumn{13}{|l|}{$w t . \%$} \\
\hline$S$ & 52.85 & 52.69 & 53.39 & 52.38 & 52.63 & 52.91 & 52.31 & 52.28 & 52.07 & 51.75 & 52.46 & 51.48 \\
\hline $\mathrm{Fe}$ & 46.80 & 47.05 & 46.19 & 46.87 & 46.61 & 46.05 & 46.09 & 46.64 & 46.37 & 46.32 & 45.36 & 46.24 \\
\hline As & 0.12 & 0.05 & 0.18 & 0.12 & 0.02 & 1.34 & 1.10 & 0.81 & 1.06 & 1.24 & 1.68 & 1.42 \\
\hline Co & - & - & - & - & - & - & - & - & - & - & - & - \\
\hline $\mathrm{Zn}$ & 0.04 & 0.02 & - & - & - & - & - & - & 0.01 & - & - & 0.03 \\
\hline $\mathrm{Bi}$ & - & - & - & - & - & - & - & 0.19 & - & - & - & - \\
\hline $\mathrm{Cu}$ & 0.01 & 0.01 & 0.01 & 0.01 & 0.01 & 0.01 & 0.01 & - & - & 0.01 & 0.01 & 0.01 \\
\hline $\mathrm{Sb}$ & - & - & - & - & - & - & - & - & - & 0.03 & - & 0.01 \\
\hline $\mathrm{Au}$ & - & - & - & - & - & 0.015 & 0.016 & - & - & - & 0.014 & 0.018 \\
\hline $\mathrm{Ni}$ & - & - & - & - & - & - & - & - & 0.01 & - & - & - \\
\hline $\mathrm{Te}$ & - & 0.06 & - & - & - & - & - & - & 0.02 & - & - & - \\
\hline $\begin{array}{l}\text { Total } \\
\text { atomic \% }\end{array}$ & 99.89 & 99.94 & 99.78 & 99.46 & 99.28 & 100.34 & 99.53 & 99.93 & 99.58 & 99.36 & 99.54 & 99.21 \\
\hline$S$ & 66.32 & 66.14 & 66.76 & 66.10 & 66.40 & 66.54 & 66.02 & 65.84 & 65.79 & 65.72 & 66.23 & 65.55 \\
\hline $\mathrm{Fe}$ & 33.72 & 33.90 & 33.12 & 33.96 & 33.76 & 32.81 & 33.35 & 33.67 & 33.60 & 33.77 & 32.84 & 33.80 \\
\hline As & 0.06 & 0.03 & 0.10 & 0.07 & 0.01 & 0.62 & 0.59 & 0.44 & 0.58 & 0.67 & 0.91 & 0.77 \\
\hline $\mathrm{Zn}$ & 0.03 & 0.01 & & & & & & & 0.01 & & & 0.01 \\
\hline $\mathrm{Bi}$ & 0.01 & 0.01 & & 0.01 & & & & 0.04 & & & & \\
\hline $\mathrm{Cu}$ & 0.01 & 0.01 & 0.005 & 0.01 & 0.01 & 0.004 & 0.005 & & & 0.01 & 0.01 & \\
\hline $\mathrm{Sb}$ & & & & & & & & & & 0.01 & & 0.01 \\
\hline $\mathrm{Au}$ & & & & & & 0.001 & 0.003 & & & & 0.003 & 0.004 \\
\hline $\mathrm{Ni}$ & & & 0.01 & 0.01 & & & & & 0.01 & & & \\
\hline $\mathrm{Te}$ & & 0.02 & & & & & & & 0.01 & & & \\
\hline
\end{tabular}

-: below the minimum limit of detection.

diagram of figure 6 the concentrations of Au versus the concentration of As of the Py-II crystals analyzed in the area have been plotted. Also included are Au-bearing pyrite analyses of some other $\mathrm{Au}$ deposits from NW Spain such as Salave (MartínIzard \& Rodríguez-Terente, 2009), Salamón (Fadón Loro, 2007), El Valle-Boinás (Cepedal et al., 2008) and Arcos (Martínez-Abad et al., 2015b). In this study we suggest that $\mathrm{Au}$ in Py-II from ValiñaAzúmara is present as solid solution $\left(\mathrm{Au}^{+1}\right)$ since the $\mathrm{Au} / \mathrm{As}$ ratios plot below the solubility limit proposed by Reich et al. (2005). The same is observed in the El Valle-Boinás deposit (Cepedal et al., 2008). However, in the Arcos deposit of the Vilalba gold district, as well as in Salave and Salamón, Au occurs both as solid solution and as nanoparticles within the pyrite (Fadón Loro, 2007;
Martín-Izard \& Rodríguez-Terente, 2009; MartínezAbad et al., 2015b).

\section{Second stage of mineralization (Ag-Pb-Zn-Cu-Sb)}

This stage of mineralization consists of chlorite, quartz and minor calcite in addition to metallic minerals such as sphalerite, jamesonite $\left(\mathrm{Pb}_{4} \mathrm{FeSb}_{6} \mathrm{~S}_{14}\right)$, $\mathrm{Cu}-\mathrm{Ag}$ sulfosalts (tetrahedrite-freibergite series) and minor chalcopyrite, pyrrhotite and galena (Fig. 7). These minerals occur as a second generation of filling in the structures previously described, suggesting reopening of the preexisting fractures, encompassing and partially replacing the minerals of the previous mineralization stage. The earlier deposited pyrite and arsenopyrite frequently reveal microfractures sealed by gangue and metallic minerals from this stage (Fig. 7D). 


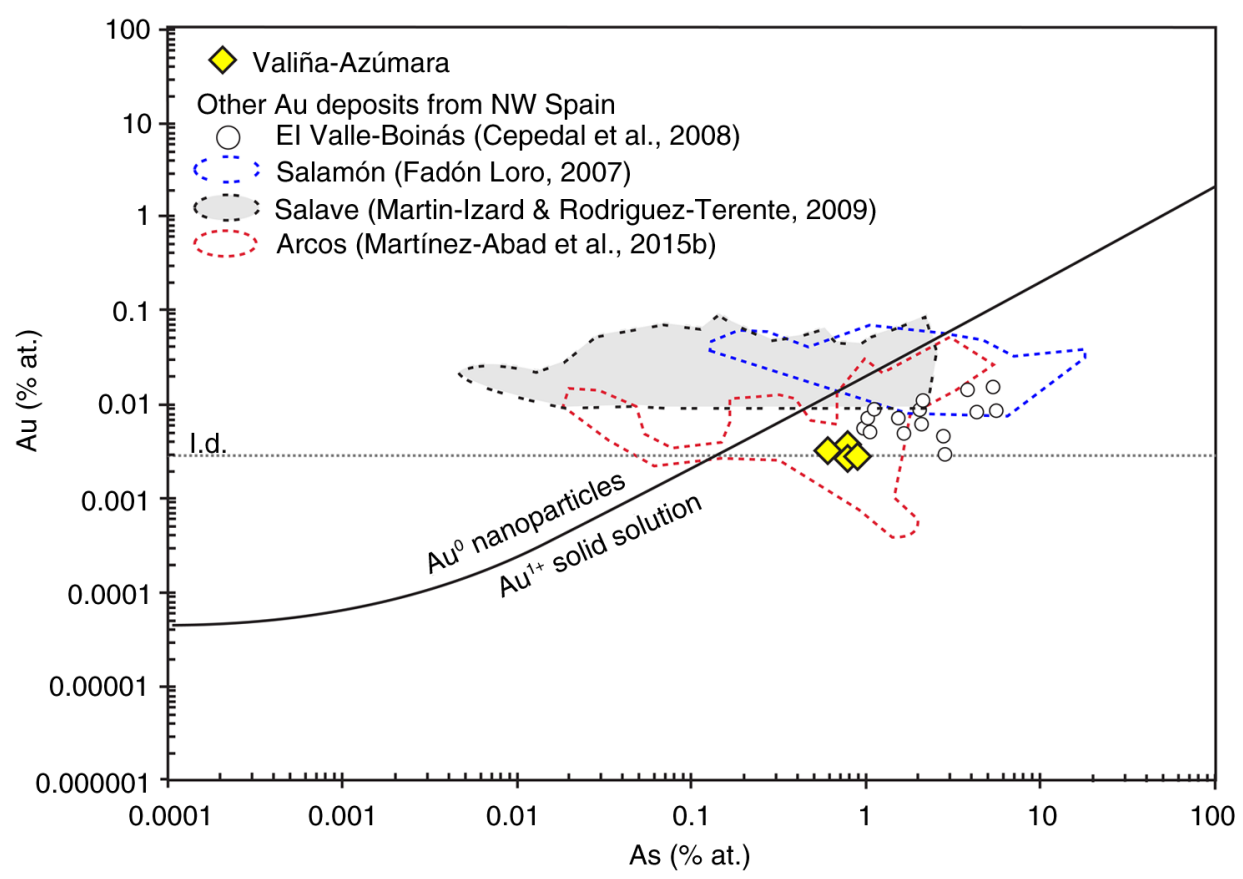

Fig. 6.-Au-As plot of Au-bearing Py-II. The solubility limit for Au proposed by Reich et al. (2005) is represented by the curve $C_{A u}=0.02 \times C_{A s}+4 \times 10^{-5}$, where $C_{A u}$ and $C_{A s}$, represent the concentration of $A u$ and $A s$ in atomic percent (at.\%). Above this line, Au is in the form of nanoparticles of native gold whereas, below it, Au is considered to be present in solid solution. I.d.: limit of detection of $\mathrm{Au}(140 \mathrm{ppm})$ for the analyses carried out in Valiña-Azúmara Py-II (dashed line). Also included in the diagram are the analyses of Au-bearing pyrites from other Au deposits of NW Spain.

Sphalerite is the most abundant ore mineral of this stage. It occurs as anhedral dark red grains, usually below $1 \mathrm{~mm}$ in diameter (Fig. 7C, 7E and 7F). The Fe content of the sphalerite varies between 4.2 and 7.2 wt.\% (Table 4). The sphalerite usually occurs intergrown with $\mathrm{Cu}-\mathrm{Ag}$ sulfosalts and jamesonite. In addition, these last two minerals and, especially pyrrhotite and chalcopyrite, may occur within the sphalerite, forming inclusions and small elongated patches $(<30 \mu \mathrm{m})$ along perpendicular crystallographic directions ("chalcopyrite disease") (Fig. 7F).

Jamesonite forms aggregates of tabular grains with a diameter of up to $500 \mu \mathrm{m}$. It occurs isolated as well as intergrown with $\mathrm{Cu}-\mathrm{Ag}$ sulfosalts and sphalerite (Fig. 7B and 7C). Furthermore, on occasions it forms small inclusions within the sphalerite grains. Chemically, it should be noted that on some occasions jamesonite contains traces of $\mathrm{Ag}$ (of up to 0.22 wt. \%; Table 4) .

The $\mathrm{Cu}$-Ag sulfosalts form subhedral to anhedral grains of up to $1 \mathrm{~mm}$ in diameter. They are normally intergrown with jamesonite (Fig. 7A and 7B) and, on some occasions, occur as small inclusions within the sphalerite grains. The $\mathrm{Cu}-\mathrm{Ag}$ sulfosalts of ValiñaAzúmara belong to the tetrahedrite-freibergite solid solution series. Chemically, they have contents in $\mathrm{Cu}$ ranging from 22.3 to $29.4 \mathrm{wt} . \%$. Together with the chalcopyrite, they are the main $\mathrm{Cu}$-bearing minerals in the deposit. In addition, these sulfosalts show significant contents in $\mathrm{Ag}$, ranging from 13.05 to 23.9 wt.\% (Table 4). In agreement with Moëlo et al. (2008), the $\mathrm{Cu}-\mathrm{Ag}$ sulfosalts of Valiña-Azúmara have been differentiated into two different phases on the basis of their chemical composition. The variety with Ag over 4 a.p.f.u has been classified as freibergite, whereas the variety with Ag below 4 a.p.f.u has been classified as Ag-rich tetrahedrite (Table 4, Fig. 8). According to these authors, due to $\mathrm{Cu}$ being substituted by $\mathrm{Ag}$, the $\mathrm{Ag}$ concentration seems to be inversely correlated to the $\mathrm{Cu}$ concentration in the tetrahedrite-freibergite solid solution series (Fig. 8). Although, as we mentioned before, jamesonite may contain traces of $\mathrm{Ag}$, the main bearers of the Ag mineralization within the ValiñaAzúmara deposit are the Ag-rich tetrahedrite and freibergite. This fact explains the strong correlation 

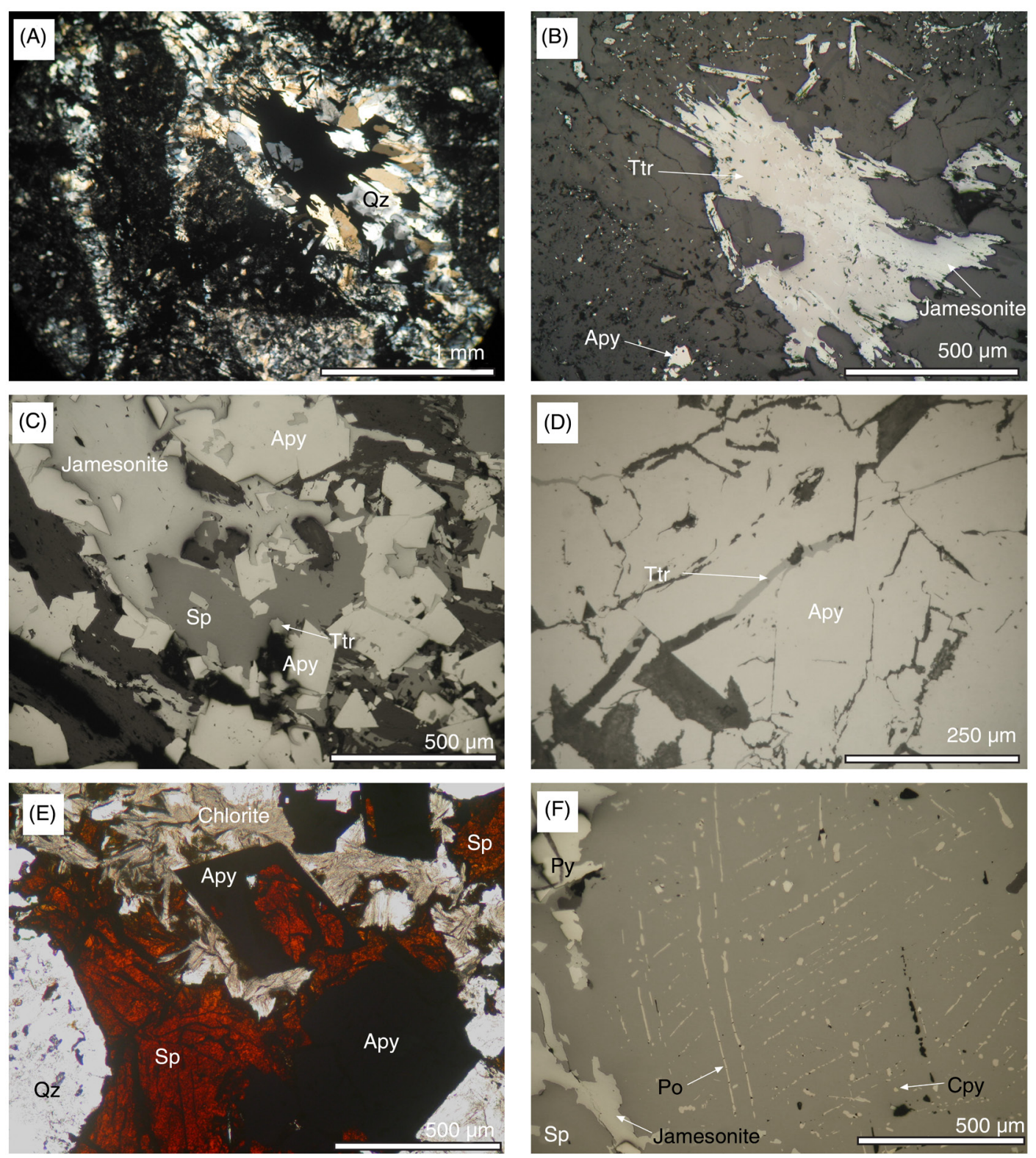

Fig. 7.-Photomicrographs of metallic assemblages from the second, Ag-Pb-Zn-Cu-Sb stage of mineralization. A. Cavity sealed by quartz (Qz) and opaque grains in a fault breccia (Cross polarized light, CPL). B. Detail of the opaque grains of photomicrograph "a" under reflected light. The Ag-rich tetrahedrite (Ttr) is intergrown with jamesonite. The arsenopyrite (Apy) was deposited earlier, during the first stage of mineralization, and occurs disseminated in the fault breccia. C. Grains of sphalerite (Sp) and jamesonite partially encompass arsenopyrite grains from the first stage of mineralization. Jamesonite also occurs filling small hollows within the arsenopyrite $(R L)$. D. Ag-rich tetrahedrite sealing a microfracture that crosscuts an arsenopyrite grain from the first stage of mineralization (RL). E. Sphalerite crystals encompassing and partially replacing arsenopyrite grains from the first stage of mineralization. In the photo it is also possible to observe the presence of abundant chlorite crystals in equilibrium with the sphalerite grains (PPL). F. Sphalerite grain with inclusions and small elongated patches $(<30 \mu \mathrm{m})$ of pyrrhotite and minor chalcopyrite along perpendicular crystallographic directions (chalcopyrite disease).

between $\mathrm{Cu}$ and $\mathrm{Ag}$ obtained in the multi-element analyses carried out on the mineralized sections of drill cores (Fig. 4B).
Chalcopyrite, galena and pyrrhotite are the least abundant ore minerals of the second stage of mineralization. They normally occur filling small hollows 
Table 4.- Representative composition of the main ore minerals of the second stage of mineralization (Ag-Pb-Zn-Cu-Sb) of Valiña-Azúmara measured by electron microprobe analyses

\begin{tabular}{|c|c|c|c|c|c|c|c|c|}
\hline \multirow{2}{*}{$\begin{array}{l}\text { Mineral } \\
\text { Analysis }\end{array}$} & \multicolumn{2}{|c|}{ Sphalerite } & \multirow{2}{*}{$\begin{array}{l}\text { Freibergite } \\
\text { V2.39C2-1 }\end{array}$} & \multicolumn{3}{|c|}{ Ag-rich tetrahedrite } & \multicolumn{2}{|c|}{ Jamesonite } \\
\hline & $\mathrm{V} 1.49 \mathrm{C} 2-4$ & V1.49C3-1 & & V2.39C2-1 & Valtx75 & V2.39C3-1 & CR2-1 & V2.39-2 \\
\hline \multicolumn{9}{|l|}{$w t . \%$} \\
\hline S & 33.24 & 33.26 & 22.12 & 22.37 & 22.82 & 23.48 & 21.65 & 21.17 \\
\hline $\mathrm{Fe}$ & 7.27 & 4.21 & 5.04 & 5.41 & 5.61 & 5.14 & 2.56 & 3.59 \\
\hline As & 0.02 & 0.07 & 0.68 & 0.72 & 0.10 & 0.77 & 0.54 & 0.84 \\
\hline $\mathrm{Zn}$ & 58.20 & 61.15 & 0.92 & 1.08 & 0.76 & 1.31 & 0.04 & 0.05 \\
\hline $\mathrm{Bi}$ & - & - & - & - & - & - & - & - \\
\hline $\mathrm{Cu}$ & 0.02 & 0.22 & 22.35 & 23.77 & 29.44 & 25.22 & 0.05 & - \\
\hline $\mathrm{Pb}$ & - & - & 0.15 & - & 0.25 & - & 40.24 & 38.64 \\
\hline $\mathrm{Sb}$ & - & - & 24.48 & 25.58 & 28.44 & 27.20 & 35.16 & 35.87 \\
\hline $\mathrm{Au}$ & - & - & - & - & - & - & - & - \\
\hline $\mathrm{Ag}$ & - & - & 23.87 & 21.02 & 13.05 & 17.14 & 0.12 & 0.22 \\
\hline $\mathrm{Ni}$ & - & 0.01 & 0.01 & 0.08 & - & 0.10 & 0.02 & - \\
\hline $\mathrm{Te}$ & n.a. & n.a. & n.a. & n.a. & - & n.a. & - & n.a \\
\hline Co & 0.05 & - & 0.05 & - & n.a. & 0.04 & n.a & n.a \\
\hline $\mathrm{Cd}$ & 1.32 & 1.43 & - & - & n.a. & - & n.a & n.a \\
\hline \multirow[t]{2}{*}{ Total } & 100.13 & 100.34 & 99.67 & 100.03 & 100.45 & 100.40 & 100.42 & 100.39 \\
\hline & \multicolumn{2}{|c|}{ atomic \% } & To 29 atoms & \multicolumn{3}{|c|}{ To 29 atoms } & \multicolumn{2}{|c|}{ To 25 atoms } \\
\hline S & 50.11 & 50.26 & 12.68 & 12.65 & 12.56 & 12.99 & 13.91 & 13.54 \\
\hline $\mathrm{Fe}$ & 6.28 & 3.65 & 1.66 & 1.75 & 1.77 & 1.63 & 0.94 & 1.32 \\
\hline As & 0.01 & 0.04 & 0.17 & 0.17 & 0.02 & 0.18 & 0.15 & 0.23 \\
\hline $\mathrm{Zn}$ & 42.97 & 45.26 & 0.26 & 0.30 & 0.20 & 0.35 & 0.01 & 0.02 \\
\hline $\mathrm{Cu}$ & 0.02 & 0.17 & 6.46 & 6.77 & 8.17 & 7.03 & 0.02 & \\
\hline $\mathrm{Pb}$ & & & 0.01 & & 0.02 & & 3.99 & 3.82 \\
\hline $\mathrm{Sb}$ & & & 3.69 & 3.80 & 4.12 & 3.96 & 5.94 & 6.03 \\
\hline $\mathrm{Ag}$ & & & 4.06 & 3.53 & 2.13 & 2.81 & 0.02 & 0.04 \\
\hline $\mathrm{Ni}$ & & 0.01 & & 0.03 & & 0.03 & 0.01 & \\
\hline Co & 0.04 & & 0.02 & & & 0.01 & & \\
\hline $\mathrm{Cd}$ & 0.57 & 0.61 & & & & & & \\
\hline
\end{tabular}

-: below the minimum limit of detection. n.a.: not analiyzed.

in pyrite and arsenopyrite from the first stage of mineralization. Furthermore, as mentioned previously, chalcopyrite and pyrrhotite also form small elongated patches and inclusions $(<30 \mu \mathrm{m})$ within the sphalerite (Fig. 7F).

\section{Supergene alteration}

Widespread weathering affected the superficial levels of the area, producing the supergene alteration of the primary ore. The secondary minerals recognized in the deposit are iron oxides and hydroxides, scorodite $\left(\mathrm{FeAsO}_{4} \cdot 2 \mathrm{H}_{2} \mathrm{O}\right)$ and anglesite $\left(\mathrm{PbSO}_{4}\right)$.
The iron oxides and hydroxides are the most abundant secondary minerals in the deposit. They occur disseminated in the supergene-altered samples, forming thin reddish crusts (Fig. 2A). Scorodite and anglesite occur associated with the iron oxides and hydroxides. The scorodite replaces the arsenopyrite, forming thin pale green crusts, whereas anglesite replaces the $\mathrm{Pb}$-bearing minerals (jamesonite and minor galena), forming thin yellowish crusts (Fig. 2A). The oxidation of the As-rich pyrite (Py-II) must have produced the liberation of the refractory $\mathrm{Au}$ contained within this mineral. However, native $\mathrm{Au}$ has not been recognized in any of the supergene altered samples studied for this work. 


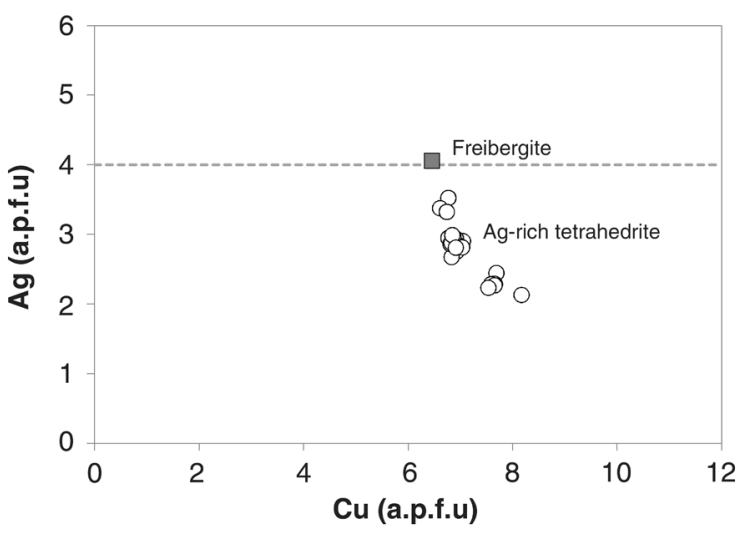

Fig. 8.-Plot of Ag versus $\mathrm{Cu}$ of the $\mathrm{Cu}$-Ag sulfosalts (freibergitetetrahedrite series) of the Valiña-Azúmara deposit. According to (Moëlo et al., 2008), within the freibergite-tetrahedrite series the mineral with Ag content above 4 a.p.f.u. is classified as freibergite (grey square), whereas that below 4 a.p.f.u. should be called Ag-rich tetrahedrite (white circle).

\section{Discussion}

Valiña-Azúmara together with the W/Au skarn of Castro de Rei and the polymetallic mineralization of Arcos constitute the Vilalba gold district (Martínez-Abad et al., 2015a). The Valiña-Azúmara mineralization is structurally and, to a lesser degree, lithologically controlled. As previously mentioned, Variscan thrust fault $\left(\mathrm{D}_{2}\right)$ and N-S, NE-SW LateVariscan faults hosted the mineralization. The occurrence of a NE-SW trending felsic dike in the north sector of the area (Fig. 1B) indicates these LateVariscan faults allowed the intrusion of post-tectonic igneous rocks in addition to the migration of the mineralizing fluids. The felsic dike outcropping in the area has been interpreted as part of the dike suite of a post-tectonic granitoid lying beneath the Castro de Rei area, where the occurrence of contact aureole hornfels and the skarn mineralization, with maximum temperatures of formation of between 520 and $560{ }^{\circ} \mathrm{C}$, evidences the presence of a blind granitic body (Martínez-Abad et al., 2015a). Igneous rocks of a similar type have also been observed forming dikes and sills at the deposit of Arcos, located around $6 \mathrm{~km}$ to the south of Valiña-Azúmara (Martínez-Abad et al., 2015b).

The mineralization of Valiña-Azúmara occurs cementing fault breccias and forming veins and, to a lesser extent, as dissemination in the altered host rocks, which mainly consist of black slates.
Contrary to what is observed in the nearby area of Castro de Rei, the black slates show no evidence of being affected by contact metamorphism. Hydrothermal alteration of host-rocks produced sericitization in the selvages of veins and fault breccias, rarely pervasive. The biotite of the slates was altered to muscovite together with rutile and fine-grained sulfides and sulfoarsenides, evidencing sulfidation processes. Silicification also occurs but, unlike the polymetallic mineralization of Arcos, where silicification is locally pervasive and develops jasperoids (Martínez-Abad et al., 2015b), the presence of lesscarbonated rocks in Valiña-Azúmara implies this type of hydrothermal alteration is not well-developed. This type of hydrothermal alteration indicates the presence of an acid ore-forming fluid that barely reacts with the pelitic rocks of Valiña-Azúmara but reacts strongly with the alkaline limestones of Arcos.

The metallic paragenesis of Valiña-Azúmara, consisting of a first stage of mineralization with arsenopyrite and pyrite and a second stage with base metal sulfides and $\mathrm{Pb}-\mathrm{Sb}-\mathrm{Ag}$ sulfosalts, reflects the geochemistry signature of the area. If we compare the multielemental analysis carried out on drill-core mineralized samples from the Valiña-Azúmara and the Castro de Rei skarn (Bi up to 1310 ppm; Te up to $41 \mathrm{ppm}$; Mo up to $247 \mathrm{ppm}$; W up to $431 \mathrm{ppm}$; $\mathrm{Au}$ up to $6.4 \mathrm{ppm}$; $\mathrm{As}>2 \%$; $\mathrm{Ag}$ up to $28 \mathrm{ppm}$; $\mathrm{Sb}$ up to $3175 \mathrm{ppm}$; $\mathrm{Cu}$ up to $1851 \mathrm{ppm}$; $\mathrm{Pb}$ up to $7000 \mathrm{ppm}$; and $\mathrm{Zn}$ up to $3590 \mathrm{ppm}$; Martínez-Abad, 2013), the former is enriched in $\mathrm{As}, \mathrm{Ag}, \mathrm{Pb}, \mathrm{Zn}$ and $\mathrm{Sb}$ with respect to Castro de Rei, whereas the Castro de Rei skarn is enriched in $\mathrm{W}, \mathrm{Bi}, \mathrm{Te}, \mathrm{Cu}, \mathrm{Au}$ and Mo with respect to Valiña-Azúmara.

The deposition of gold in Valiña-Azúmara took place during the first stage of mineralization, since the only gold detected was in EMPAs of As-rich pyrites (Py-II). The Au/As ratios of Py-II suggest it formed from solutions that were not saturated in Au. Sulfidation processes, such as the one observed in Valiña-Azúmara, are proposed as the principal mechanism of deposition of invisible Au in Carlin Type and epithermal ore deposits, where it is generally accepted that Au is transported as a bisulfide complex. According to Reich et al. (2005), in solutions not saturated in $\mathrm{Au}$ such as Valiña-Azúmara, the decrease in $\mathrm{H}_{2} \mathrm{~S}$ produced by sulfidation strongly favors the formation of arsenian pyrite and incorporation of $\mathrm{Au}$ 
as solid solution. It may therefore be reasonable to deduce that in the altered rocks of Valiña-Azúmara the hydrothermal solution transporting $\mathrm{Au}$ as bisulfide complexes reacted with liberated iron from the previous Fe-bearing minerals (biotite) in the rock and precipitated $\mathrm{Au}$ together with As-bearing iron sulfides.

Martínez-Abad et al. (2015a) proposed an intrusion-related gold system model (IRGS, Lang \& Baker, 2001) for the mineralizations of the Vilalba gold district. According to Lang and Baker (2001), the IRGSs comprise a group of magmatic-hydrothermal gold deposits hosted primarily within intrusions or in adjacent wall rocks. Based on their spatial relationship to intrusions, these deposits can be separated into the following three categories: Intrusionhosted deposits comprising auriferous vein deposits (Au-Bi $\pm \mathrm{Te} \pm \mathrm{As} \pm \mathrm{Mo} \pm \mathrm{W}$ ); proximal deposits located adjacent to the intrusion, within the metamorphic aureole, and including $\mathrm{W} \pm \mathrm{Cu} \pm \mathrm{Au}$ and $\mathrm{Cu}-\mathrm{Bi}-\mathrm{Au} \pm \mathrm{W}$ skarns and Au-As veins; distal deposits located beyond the outer limit of hornfels and having a typical metal signature of $\mathrm{Au}-\mathrm{As}-\mathrm{Sb}-\mathrm{Hg} \pm \mathrm{Ag}-\mathrm{Pb}-\mathrm{Zn}(\mathrm{Au})$. They normally include mesothermal to epithermal auriferous quartz-sulfide veins along steep faults, base-metal veins enriched in $\mathrm{Ag} \pm \mathrm{Au}$, and $\mathrm{Au}$ disseminations in calcareous and carbonaceous sedimentary rocks (Lang \& Baker, 2001). The Ag-Pb-Zn-(Au) metal association may form individual veins or representing the youngest stage of mineralization within other deposit types, and may include pyrrhotite, galena, sphalerite, $\mathrm{Pb}$-Sb sulfosalts and Ag-bearing sulfosalts such as tetrahedrite and freibergite as ore minerals.

According to Martínez-Abad et al. (2015a), the W/Au skarn of Castro de Rei and the polymetallic mineralization of Valiña-Azúmara constitute an IRGS. The skarn represents a proximal deposit with respect to an unexposed granitoid, and the ValiñaAzúmara represents a distal deposit developed in the peripheral or distal zones with respect to the granitic body, outside the contact aureole. Furthermore, these deposits show the characteristic metal signature of the IRGSs, with metals such as W, Mo, Bi and Te precipitated in the high-temperature proximal deposit of Castro de Rei, while distal and cooler areas like Valiña-Azúmara are enriched in elements such as $\mathrm{As}-\mathrm{Ag}-\mathrm{Pb}$ and $\mathrm{Zn}$.
Finally, Valiña-Azúmara shows many similarities with the polymetallic deposit of Arcos, which shows the same geochemical signature Au-As $(\mathrm{Ag}-\mathrm{Pb}-\mathrm{Zn}-\mathrm{Cu}-\mathrm{Sb})$ and has also been interpreted as a distal deposit from an IRGS. In both deposits, the ore appears filling fractures and the paragenesis starts with an early Au-As stage of mineralization, with $\mathrm{Au}$ occurring mainly as invisible Au. Arsenopyrite and pyrite are the main sulfide minerals during this stage and sericitization, silicification and sulfidation are the main hydrothermal alteration processes. Unlike Arcos, the area of Valiña-Azúmara lacks reactive calcareous rocks, which implies a significantly lesser volume of hydrothermally altered rocks and, therefore, disseminated mineralization. Both deposits contain a second stage of mineralization dominated by sphalerite and $\mathrm{Pb}-\mathrm{Sb}-\mathrm{Ag}$ sulfosalts that, as previously mentioned, are characteristic of the Ag-Pb-Zn-(Au) metal association of the IRGS. In contrast to Valiña-Azúmara, tetrahedrite (up to $4.3 \mathrm{wt} \%$ of $\mathrm{Ag}$ ) and accessory electrum (up to $27.7 \mathrm{wt} \%$ of $\mathrm{Ag}$ ) are the main Ag-bearing minerals in Arcos. These deposits show similarities with the deposits of Salamón (Crespo et al., 2000) in the NW Iberian Massif, and Brevery Creek (Diment \& Craig, 1998) in Yukon (Canada), considered by Lang \& Baker (2001) to be good examples of IRGS distal deposits.

\section{Conclusions}

The mineralization of Valiña-Azúmara is structurally controlled. It is mainly hosted in a Variscan thrust fault $\left(\mathrm{D}_{2}\right)$ with a dip direction of $\mathrm{N} 247-261^{\circ} \mathrm{E}$ and a dip of $35^{\circ}$, that affects Lower Cambrian black slates. To a lesser extent, it also occurs filling Late Variscan $\mathrm{N}-\mathrm{S}$ faults with a dip direction of $\mathrm{N} 266-285^{\circ} \mathrm{E}$ and dip between $70^{\circ}$ and $90^{\circ}$, and Late Variscan NE-SW, with a dip direction of $\mathrm{N} 300-309^{\circ} \mathrm{E}$ and dip between $55^{\circ}$ and $68^{\circ}$. The mineralization occurs cementing fault breccias and forming hydrothermal veins. To a lesser extent, it also occurs disseminated in weakly sericitized and silicified fault breccias and fracture walls of up to $4 \mathrm{~cm}$ in thickness.

The multi-element analyses carried out on mineralized sections of drill cores in Valiña-Azúmara reflect the geochemical signature of the mineralization, showing significant contents in $\mathrm{Au}$ (up to $2.06 \mathrm{ppm}$ ), 
As (up to 12.7\%), $\mathrm{Ag}$ (up to $487 \mathrm{ppm}$ ), $\mathrm{Pb}$ (up to $4.4 \%$ ), $\mathrm{Zn}$ (up to $1.5 \%$ ), $\mathrm{Cu}$ (up to $600 \mathrm{ppm}$ ), and $\mathrm{Sb}$ (up to $3600 \mathrm{ppm}$ ). Geochemically, Au shows a significant correlation with $\mathrm{As}\left(\mathrm{R}^{2}=0.66\right)$ and $\mathrm{Ag}$ shows a strong correlation with $\mathrm{Cu}\left(\mathrm{R}^{2}=0.9\right)$.

The mineral paragenesis is divided into two hypogene stages. The first is characterized by a Au-As metal association and consists of arsenopyrite and pyrite as ore minerals and quartz, rutile, sericite and minor calcite as gangue minerals. The arsenopyrite crystals commonly display an oscillatory zoning in As (43.45 to 46.9 wt.\% in As), showing As-poor cores with respect to the rims. They often contain impurities of $\mathrm{Sb}, \mathrm{Cu}$ and Ni. However, no traces in Au were detected in this mineral. Two different types of pyrites (Py-I and Py-II) were differentiated. Py-I commonly forms a core overgrown and partially corroded by Py-II. While Py-I is poor in As and lacks of traces of other elements, Py-II is As-rich $(\leq 1.7 \mathrm{wt} . \%)$ and often contains traces of other elements such as $\mathrm{Te}, \mathrm{Zn}, \mathrm{Cu}, \mathrm{Bi}, \mathrm{Sb}$ and $\mathrm{Au}$. Gold occurs as refractory $\mathrm{Au}$ within the As-rich pyrite (Py-II), showing concentrations of up to $176 \mathrm{ppm}$. The $\mathrm{Au} / \mathrm{As}$ ratios of Py-II suggest that $\mathrm{Au}$ is present as solid solution $\left(\mathrm{Au}^{+1}\right)$ within this sulfide and, therefore, that the hydrothermal ore-forming fluid was not saturated with respect to $\mathrm{Au}$.

The second stage of mineralization is characterized by a $\mathrm{Ag}-\mathrm{Pb}-\mathrm{Zn}-\mathrm{Cu}-\mathrm{Sb}$ metal association. It replaces the first stage (Au-As) and consists of sphalerite, jamesonite, Ag-rich tetrahedrite, freibergite, chalcopyrite, pyrrhotite and galena as ore minerals and quartz, calcite and chlorite as gangue minerals. This stage is sealing open spaces as cavities and microfractures that crosscut the ore minerals of the first stage (Au-As) of mineralization. Sphalerite shows contents in Fe of up to 7.2 wt.\%. The main bearers of the $\mathrm{Ag}$ mineralization in the deposit are the Ag-tetrahedrite (from 13.05 to $21.02 \mathrm{wt.} \%$ in $\mathrm{Ag}$ ) and the freibergite (up to 23.9 wt.\% in Ag), although jamesonite on occasions also contains trace amounts of $\mathrm{Ag}(\leq 0.22 \mathrm{wt} . \%)$.

Eventually, secondary $\mathrm{Fe}$ oxide and hydroxide, scorodite and anglesite developed due to the oxidation of the ore in the most superficial areas. The oxidation of the As-rich pyrite (Py-II) must have produced the liberation of the refractory Au contained within this mineral, though, native Au has not been recognized in the altered samples.

\section{ACKNOWLEDGMENTS}

This work has been financed by the CICYT projects CGL2007-62298 and CGL2011-23219 and supported by FPI of the Educational Science Ministry of Spain (BES-2008-002954) grant to Martínez-Abad. The authors wish to thank two anonymous reviewers, as well as the chief editor José María Cebriá Gómez, for their constructive comments and suggestions that greatly improved this manuscript.

\section{References}

Amor Meilán, M. (2005). Recuperando textos (V), Amor Meilán, "Castro de Rei” (1928). Boletín CROA, 15: $17-25$.

Bakken, B.M.; Hochella, M.F. Jr.; Marshall, A.F. \& Tunner, A.M. (1989). High-resolution microscopy of gold in unoxidized ore from the Carlin mine, Nevada. Economic Geology, 84: 171-179. http://dx.doi.org/ 10.2113/gsecongeo.84.1.171

Bastida, F.; Martínez Catalán, J.R. \& Pulgar, J.A. (1986). Structural, metamorphic and magmatic history of the Mondoñedo nappe (Hercynian belt, NW Spain). Journal of Structural Geology, 8: 415-430. http:// dx.doi.org/10.1016/0191-8141(86)90060-X

Bellido Mulas, F.; González-Lodeiro, F.; Klein, E.; Martínez Catalán, J.R. \& Pablo Macia, J.G. (1987). Las rocas graníticas hercínicas del norte de Galicia y occidente de Asturias. Instituto Geológico y Minero de España, Madrid, 157 pp.

Cabri, L.J.; Newville, M.; Gordon, R.A.; Crozier, E.D.; Sutton, S.R.; McMahon, G. \& Jiang, D. (2000). Chemical speciation of gold in arsenopyrite. The Canadian Mineralogist, 38 (5): 1265-1281. http:// dx.doi.org/10.2113/gscanmin.38.5.1265

Capdevila, R. (1969). Le métamorphisme régional progressif et les granites dans le segment hercynien de Galice Nord orientale (NW de l'Espagne) Tesis Doctoral. Universidad de Montpellier, $430 \mathrm{pp}$.

Capote, R. (1983). La fracturación subsecuente a la orogenia varisca. In: Geología de España, II (Comba, J.A., Ed.). Instituto Geológico y Minero de España, Madrid, 17-24.

Cepedal, A.; Fuertes-Fuente, M.; Martín-Izard, A.; González Nistal, S. \& Barrero, M. (2008). Gold-bearing As-rich pyrite and arsenopyrite from the El Valle gold deposit, Asturias, Northwestern Spain. The Canadian Mineralogist, 46 (1): 233-247. http://dx.doi.org/10.3749/ canmin.46.1.233

Cocherie, A. (1978) Géochimie des terres rares dans le granitoides. Tesis Doctoral, Universidad de Rennes, $207 \mathrm{pp}$.

Corretgé, L.G.; Suárez, O. \& Galán, G. (1990). WestAsturianLeonese Zone. Igneous rock. In: Pre-Mesozoic geology of Iberia, (Dallmeyer, R.D. \& Martínez García, E., Eds.). Springer- Verlag, Berlín, 115-128. 
Crespo, J.L.; Moro, M.C.; Fadón, O.; Cabrera, R. \& Fernández, A. (2000). The Salamón gold deposit (León, Spain). Journal of Geochemical Exploration, 71 (2): 191-208. http://dx.doi.org/10.1016/S03756742(00)00152-7

Deditius, A.P.; Reich, M.; Kesler, S.E.; Utsusomiya, S.; Chryssoulis, S.L.; Walshe, J. \& Ewing, R.C. (2014). The coupled geochemistry of Au and As in pyrite from hydrothermal ore deposits. Geochimica et Cosmochimica Acta, 140: 644-670. http://dx.doi.org/10.1016/j. gca.2014.05.045

Diment, R. \& Craig, S. (1998). Brewery Creek gold deposit, central Yukon. Yukon Exploration and Geology: 225-230.

Fadón Loro, O. (2007). Las mineralizaciones hidrotermales de Au-As-(Sb, Zn, Cu-Ni-Co, Hg, U) del Distrito Minero de Salamón (NE León). Tesis doctoral, Universidad de Salamanca. 334 pp.

Friedl, J.; Wagner, F.E.; Wang, N. (1995). On the chemical state of combined gold in sulfidic ores: conclusions from Mössbauer source experiments. Neues Jahrbuch für Mineralogie Abhandlungen, 169: 279-290.

Gómez-Fernández, F.; Vindel, E.; Martín-Crespo, T.; Sánchez, V.; González Clavijo, E. \& Matías, R. (2012). The Llamas de Cabrera gold district, a new discovery in the Variscan basement of northwest Spain: a fluid inclusion and stable isotope study. Ore Geology Reviews, 46: 68-82. http://dx.doi.org/10.1016/j. oregeorev.2012.02.001

González Lodeiro, F.; Martínez Catalán, J.R.; Pablo Maciá. J.G. \& Pérez González, A. (1979). Mapa y Memoria explicativa de la hoja $n^{\circ} 58$ (Meira) del Mapa geológico de España 1:50.000. Instituto Geológico y Minero de España.

González Lodeiro, F.; Hernández Urroz. J.; Klein, E.; Martínez Catalán, J.R. \& Pablo Maciá. J.G. (1982). Mapa y Memoria explicativa de la hoja ${ }^{\circ} 8$ (Lugo) del Mapa geológico de España 1:200.000. Instituto Geológico y Minero de España.

IGME. (1972). Mapa metalogenético de oro de España. $1: 1.500 .000$.

IGME. (1975). Hoja 8 (Lugo) del Mapa Metalogenético de España. 1:200.000.

Lang, J.R. \& Baker, T. (2001). Intrusion-related gold systems: the present level of understanding. Mineralium Deposita, 36: 477-489. http://dx.doi.org/ $10.1007 / \mathrm{s} 001260100184$

Martín-Izard, A. \& Rodríguez-Terente, L. (2009). Invisible gold at the Salave Deposit, NW Spain. In: Smart Science for Exploration and Mining (Williams, P.J. et al., Eds.). Economic Geology Research Unit, James Cook University, 725-727.

Martínez-Abad, I. (2013). Geología, mineralogía y metalogenia de las mineralizaciones del distrito aurífero de Vilalba, Lugo (Noroeste de España). Tesis doctoral, Universidad de Oviedo. http://hdl.handle.net/ $10651 / 21884$
Martínez-Abad, I.; Cepedal, A.; Arias, D. \& Martín-Izard, A. (2015a). The Vilalba gold district, a new discovery in the Variscan terranes of the NW of Spain: A geologic, fluid inclusion and stable isotope study. Ore Geology Reviews, 66: 344-365. http://dx.doi. org/10.1016/j.oregeorev.2014.10.021

Martínez-Abad, I.; Cepedal, A.; Arias, D. \& FuertesFuente, M. (2015b). The Au-As (Ag-Pb-Zn-Cu-Sb) vein-disseminated deposit of Arcos (Lugo, NW Spain): Mineral paragenesis, hydrothermal alteration and implications in invisible gold deposition. Journal of Geochemical Exploration, 151: 1-16. http://dx.doi. org/10.1016/j.gexplo.2014.11.019

Martínez Catalán, J.R. (1985). Estratigrafía y estructura del Domo de Lugo (Sector Oeste de la Zona Asturoccidental-leonesa). Corpus Geologicum Gallaeciae (2a Serie), 2: 1-291.

Martínez Catalán, J.R.; Pérez Estaún, A.; Bastida, F.; Pulgar, J.A. \& Marcos, A. (1990). West AsturianLeonese Zone. Structure. In: Pre-Mesozoic Geology of Iberia (Dallmeyer, R.D. \& Martínez García, E., Eds.). Springer-Verlag, Berlín, 103-114. http://dx.doi. org/10.1007/978-3-642-83980-1 9

Moëlo, Y.; Makovicky, E.; Mozfova N.N.; Jambor, J.L.; Cook, N.; Pring, A.; Paar, W.; Nickel, E.H.; Graeser, S.; Karup-Moller, S.; Balic-Zunit, T.; Mumme, G.W.; Vurro, F.; Topa, D.; Bindi, L.; Bente, K. \& Shimizu, M. (2008). Sulfosalt systematics: a review. Report of the Sulfosalt Sub-commitee of the IMA. Commission on Ore Mineralogy. European Journal of Mineralogy, 20: 7-46. http://dx.doi.org/10.1127/ 0935-1221/2008/0020-1778

Palenik, C.S., Utsonomiya, S., Reich, M., Kesler, S.E., Ewing, R.C. (2004). Invisible gold revealed: direct imaging of gold nanoparticles in a Carlin-type deposit. American Mineralogist, 89: 1359-1366. http://dx.doi. org/10.2138/am-2004-1002

Paniagua, A.; Rodríguez Pevida, L.S.; Loredo, J.; Fontboté, L. \& Fenoll Hach-Alí, P. (1996). Un yacimiento de $\mathrm{Au}$ en carbonatos del Orógeno Hercínico: el área de Salamón (N León). Geogaceta, 20 (7): 1605-1608.

Pérez-Estaún, A.; Bastida, F.; Martínez Catalán, J.R.; Gutiérrez-Marco, J.C., Marcos, A. \& Pulgar, J.A. (1990). West Asturian-Leonese Zone. Stratigraphy. In: Pre-Mesozoic Geology of Iberia (Dallmeyer, R.D. y Martínez García, E., Eds.). Springer-Verlag, Berlín, 92-102. http://dx.doi.org/10.1007/978-3-64283980-1 8

Schulz, G. (1835). Descripción geognóstica del Reino de Galicia. Imprenta de los Herederos de Collado, Madrid. 52 pp.

Simon, G.; Huang, H.; Penner-Hahn, J.E.; Kesler, S.E. \& Kao, L.S. (1999a). Oxidation state of gold and arsenic in gold-bearing arsenian pyrite. American Mineralogist, 84: 1071-1079.

Simon, G.; Kesler, S.E. \& Chryssoulis, S. (1999b). Geochemistry and textures of gold-bearing arsenian 
pyrite, Twin Creeks, Nevada: implications for deposition of gold in Carlin-type deposits. Economic Geology, 94: 405-421. http://dx.doi.org/10.2113/ gsecongeo.94.3.405

Spiering, E.D.; Pevida, L.R.; Maldonado, C.; González, S.; García, J.; Varela, A.; Arias, D. \& Martín-Izard, A. (2000). The gold belts of Western Asturias and Galicia (NW Spain). Journal of Geochemical Exploration, 71: 89-101. http://dx.doi.org/10.1016/ S0375-6742(00)00147-3

Reich, M.; Kesler, S.E.; Utsunomiya, S.; Palenik, C.S.; Chyssoulis, S.L. \& Ewing, R.C. (2005). Solubility of gold in arsenian pyrite. Geochimica et Cosmochimica
Acta, 69: 2781-2796. http://dx.doi.org/10.1016/j. gca.2005.01.011

Villa, L., Arias, D., Suárez, O. \& Corretgé, L.G. (1993). Distribución y caracterización del oro libre y refractario presente en los filones de cuarzo-arsenopirita de las minas de Penedela, Fornaza y Río de Porcos (límite entre Lugo y Asturias). Cadernos do Laboratorio Xeolóxico de Laxe, 18: 81-88. http://hdl.handle. net/2183/6139

Walter, R. (1966). Resultado de investigaciones geológicas en el Noreste de la Provincia de Lugo (NO España). Notas y Comunicaciones del Instituto Geológico Minero de España, 89: 7-16. 